\title{
SEMEN QUALITY PARAMETERS OF ADULT MALE NZW RABBITS FED DIETS ADDED WITH TWO DIFFERENT TYPES OF PROBIOTICS
}

\author{
F.I.S. Helal ${ }^{1}$, A.Y. El- Badawi ${ }^{1}$, G. A. Abou-ward ${ }^{1}$, Soad El-Naggar ${ }^{\text {i }}$, A. A. Hassan ${ }^{2}$, M. \\ M. Basyoney ${ }^{3}$, and A. A. A. Morad ${ }^{1}$ \\ 1- Animal Production Department, National Research Centre, Dokki, Giza, Egypt.
}

2- By-product Utilization Department, Animal Production Research Institute, Agriculture Research Center, Dokki, Giza, Egypt.

3- Poultry Nutrition Department, Animal Production Research Institute, Agriculture Research Center, Dokki, Giza, Egypt.

*Corresponding author: soadelnaggar75@gmail.com

(Received 14/10/2017, accepted 1/11/2017)

\section{SUMMARY}

\begin{abstract}
$\mathrm{T}$ he present study was performed to evaluate the potential use of probiotics for improving semen quality of mature NZW rabbits. Twenty adult male NZW rabbits were assigned randomly into four equal groups that were fed four experimental diets for eight weeks. All experimental groups were fed a uniform rabbits pelleted diet, where (R1) diet without addition ( control), (R2) diet added with $0.1 \%$ Bacillus subtilis, (R3) diet added with $0.1 \%$ live Saccharomyces cerevisiae and (R4) diet added with $0.05 \%$ Bacillus s. $+0.05 \%$ Saccharomyces c. Semen samples were collected at $5^{\text {th }}, 6^{\text {th }}, 7^{\text {th }}$ and $8^{\text {th }}$ weeks of the experimental period from all tested rabbits to evaluate ejaculate volume, total sperm output, sperm cell concentration, advanced sperm motility, sperm abnormalities, dead spermatozoa, testosterone level, initial fructose concentration and reaction time(Libido). Results obtained revealed that adding probiotics to the diet of NEW rabbit bucks improved $(\mathrm{P}<0.05)$ their productive capability of male rabbit. Physical semen characteristics, blood testosterone level and initial fructose as well as the reaction time (Libido) were improved with supplemented diets, however these improvements for all parameters were associated with feeding the diet supplemented with Bacillus s. + Saccharomyces $c$. mixture. Therefore, it can be concluded that adding diet of buck with mixed probiotics culture of Bacillus s. and Saccharomyces $c$. in a ratio of (50:50 $\%)$ improved semen quality and reproductive performance.
\end{abstract}

Keywords: rabbits; probiotics; semen quality; reaction time.

\section{INTRODUCTION}

Developing countries like Egypt are often characterized by animal protein deficiency. This is not only because of size of farm animal's populations, but it is mainly due to the low productive and reproductive capabilities of the local animals. The increase in animal protein production may come from short-life cycle animals kept by the small farmers such as rabbits. The farming of rabbits has been encouraged to minimize the gap between demand and supply of animal protein (F.A.O. 1987). Therefore, production of rabbits had gradually increased at the last two decades in Egypt to support meat production (Rashwan and Marei, 2001 and Seleem, 2003). Rabbit production in Egypt is currently difficult due to high feeding cost. This problem has limited establishing of new rabbitaries and expansion of this kind of project. Several investigations have carried out to reduce the high cost of rabbit feed.

Several attempts have been carried out to promote the rabbit production and reproduction by using probiotics (Osman, 2005 and Seleem et al., 2007a). Probiotics have been defined as microbial dietary supplements that enhance the growth of desirable gastrointestinal microbes which beneficially affect the health of animal host (Schrezenmeir and de Vrese, 2001). The direct nutritional benefits of probiotic include feed efficiency, enzymatic contribution to digestion, inhibition of pathogenic microorganisms, and growth promoting factors (Vershuere et al., 2000). Therefore, probiotics increased feed conversion efficiency, live weight gain and resistance to diseases in growing animals (Sissons, 1989). However, few reports have studied the effect of incorporating probiotics in male rabbit diets on semen quality. 
Quality of semen is affected by many factors (health status, environmental conditions, diet, etc) which have received little scientific attention. Hence, this study aimed to evaluate bulks reproductive capability (semen quality and libido) as affected by probiotic addition (Bacillus subtilis or live saccharomyces cerevisiea alone or in a mixture $50: 50 \%$ of each).

\section{MATERIAL AND METHODS}

The present study was conducted at the Experimental Farm Station of the by-Product Utilization Department, Animal Production Institute, Agriculture Research Center, Nubaria area and Animal Production Department, National Research Center, Dokki, Giza.

\section{Animals and feeding}

The present work was lasted 8 weeks and was carried out on 20 sexual mature bucks of NZW rabbits aged about 6 months and weighted $2900 \mathrm{~g}$ in average. The animals were divided into 4 equal comparable experimental groups, the first group was fed diet (R1) without addition as control group, while the other three groups were randomly assigned to fed diets added either with $0.1 \%$ Bacillus $s$. (R2); $0.1 \%$ live Saccharomyces c. (R3) or mixture of $0.05 \%$ Bacillus $s .+0.05 \%$ Saccharomyces $c$. (R4), of Dry matter. Animals were individually housed in wired battery cages supplied with feeders for feeding and nipples for drinking. Fresh tab water was automatically available all the time. All the experimental rabbits were healthy and clinically free from parasites and were kept under the same hygienic conditions. The experimental diets were formed in a pellet form to cover nutrient requirements of the breeding phase of rabbits according to NRC (1994) recommendations. Composition and chemical analysis of the pelleted diet are shown in Table (1). Feed intake were weekly determined for all tested rabbits.

Table (1): Ingredients and chemical analysis of the experimental diets.

\begin{tabular}{|c|c|c|}
\hline Ingredients & & $\%$ \\
\hline Ground barley grains & 29 & \\
\hline Soybean meal (44 \%) & 20 & \\
\hline Yellow corn & 8.0 & \\
\hline Wheat bran & 8.0 & \\
\hline Cane-molasses & 3.0 & \\
\hline Ca.diphosphate & 1.0 & \\
\hline Sodium chloride & 0.5 & \\
\hline Minerals and vitamins mixture & 0.4 & \\
\hline DL-methionine & 0.1 & \\
\hline Alfalfa hay & 30 & \\
\hline \multicolumn{3}{|l|}{ Chemical analysis, $\%$} \\
\hline Moisture & & 10.00 \\
\hline \multicolumn{3}{|l|}{ Dry matter composition (DM) } \\
\hline Organic matter (OM) & & 93.15 \\
\hline Crude protein $(\mathrm{CP})$ & & 17.00 \\
\hline Crude fiber $(\mathrm{CF})$ & & 14.56 \\
\hline Ether extract (EE) & & 03.44 \\
\hline Nitrogen free extract (NFE) & & 58.15 \\
\hline Ash & & 06.85 \\
\hline
\end{tabular}

\section{Semen collected and evaluation:}

Semen was collected artificially at the week $5^{\text {th }}, 6^{\text {th }}, 7^{\text {th }}$ and $8^{\text {th }}$ of experimental period via an artificial vagina. Individual semen samples were evaluated microscopically from each rabbit buck. Semen ejaculate volume $(\mathrm{ml})$, advanced sperm motility $(\%)$, sperm cell concentration $\left(\mathrm{N} 10^{6} / \mathrm{ml}\right)$, total sperm output (N10\% /ejaculate) and sperm abnormalities (\%) as well as dead spermatozoa were estimated according to Salisbury et al. (1978). Libido (sexual desire) was assessed in terms of reaction time in seconds that was spent from introducing the doe to the buck until the buck start to mount (Daader et al. 1999a,b). Testosterone hormone concentration of the rabbit bucks was determined according to the manufacturer information (RIA kits from Immunotech, A Coulter Co., France). In addition, evaluation of seminal initial fructose was carried out immediately after collection according to Mann (1948). 


\section{Statistical analysis}

Data were subjected to two way analysis of variance according to Steel and Torrie (1980) applying the general linear model procedure of SAS (2001). Significant differences between means were calculated using Duncan's Multiple Range Test (Duncan 1955).

\section{RESULTS AND DISCUSSION}

Additives in all experimental diets did not affect daily feed intake of rabbits throughout the experimental period (Fig. 1) from the week $5^{\text {th }}$ until the week $8^{\text {th }}$.

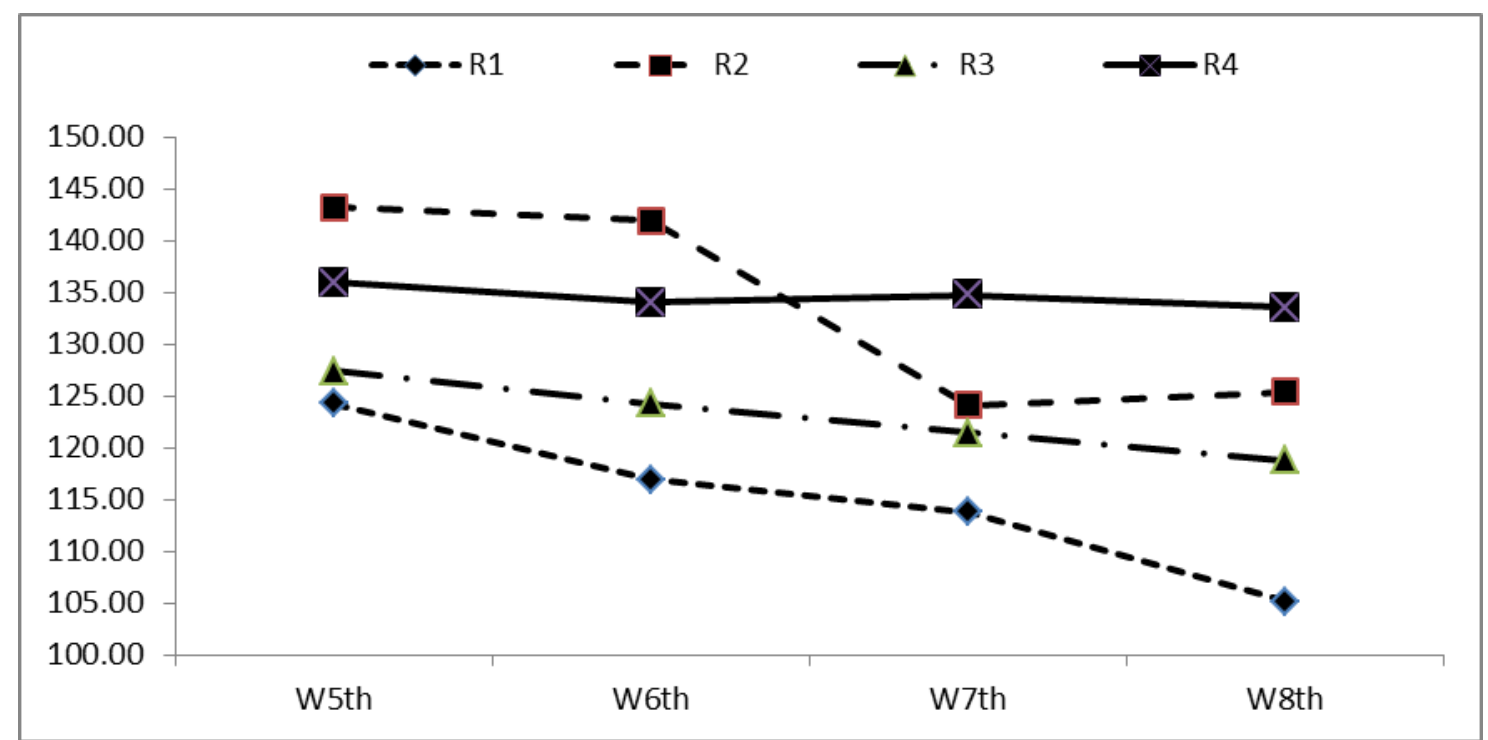

Figure (1): Effect of experimental diets and feeding period on daily feed intake of adult male rabbits.

The effect of the experimental diets on semen characteristics of tested mature male rabbits is presented in Table (2) showed an increases in semen ejaculate volume, total sperm output and sperm cell concentration of rabbits fed supplemented diets (R2, R3 and R4) compared with those fed control diet $(\mathrm{R} 1)$. It's clear that the best significant $(\mathrm{P}<0.05)$ improvement of the previous parameters was obtained by feeding rabbits on diet contained $50 \%$ Bacillus, $s .+50 \%$ Saccharomyces, $c$. (R4). These improvements may be due to enhance availability of nutrients facilitated by more efficient nutrients absorption throughout the gastrointestinal tract as a result of probiotics addition (McDaniel and Sefton, 1991), which stimulate the digestion process (El-Badawi, A.Y. et al. 2017) that attributed to the highest productive performance and/or contribute to the microbial equilibrium of the gut in order to prevent digestive disorders. This result is in agreement with other researchers who observed remarkably enhancement in total sperm cells and semen ejaculate volume of rabbit bucks, added with antioxidants (Castellini et al., 2003) or probiotics (Ewuola, 2013 and Mymrin et al., 2017). Moreover, total sperm output and sperm cell concentration were significantly $(\mathrm{P}<0.05)$ improved by advancing collection period, while semen ejaculate volume was no affected by collection period. Data in the same Table showed that the effect of interaction between the experimental diets and collection period was not significant for all semen characteristics studied.

Table (3) presents the impact of probiotics addition on physical sperm characteristics, data showed that addition of probiotics in diet $(\mathrm{R} 2, \mathrm{R} 3$ and $\mathrm{R} 4)$ significantly $(\mathrm{P}<0.05)$ increased advanced sperm motility and the highest improvement was recorded in R4 compared to R1. These results were in agreement with results obtained by Valcarce et al (2017) that the ingestion of probiotics might be recommended to improve sperm motility in human males. There were insignificant $(\mathrm{P}<0.05)$ differences among R1, R2 and R3 in sperm abnormality and between R1 and R2 in dead spermatozoa. While the lowest sperm abnormality and dead spermatozoa were recorded in R4. 
The effect of collection period regardless experimental diets in the same Table showed that there was a significant $(\mathrm{P}<0.05)$ improvement in advanced sperm motility in $\mathrm{W}^{\text {th }}$ and $\mathrm{W} 8^{\text {th }}$ compared with $\mathrm{W} 5^{\text {th }}$

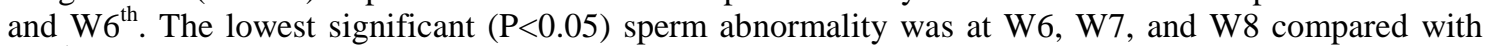
$\mathrm{W}^{\text {th }}$ of collection. Additionally, the lowest $(\mathrm{P}<0.05)$ percentage of dead spermatozoa was recorded in $\mathrm{W} 7^{\text {th }}$ and $\mathrm{W}^{\text {th }}$ compared with $\mathrm{W}^{\text {th }}$ and $\mathrm{W}^{\text {th }}$, these results reflected the beneficial effects of probiotics addition with advancing age.

Table (2): Physical semen characteristics of adult rabbit bucks as affected by the experimental diets, collection period and their interaction.

\begin{tabular}{|c|c|c|c|c|}
\hline \multirow[b]{2}{*}{ Item } & & \multicolumn{3}{|c|}{ Semen characteristics (mean) } \\
\hline & & $\begin{array}{l}\text { Semen ejaculate } \\
\text { volume },(\mathrm{ml})\end{array}$ & $\begin{array}{c}\text { Total sperm output } \\
\left(\mathrm{Nx} 10^{6} / \mathrm{ml} \text { ejaculate }\right)\end{array}$ & $\begin{array}{c}\text { Sperm cell } \\
\text { concentration } \\
\left(\mathrm{Nx} 10^{6} / \mathrm{ml}\right)\end{array}$ \\
\hline \multicolumn{5}{|c|}{ Effect of experimental diets: } \\
\hline \multicolumn{2}{|c|}{ R1 } & $0.704^{\mathrm{b}}$ & $216.294^{\mathrm{c}}$ & $304.063^{c}$ \\
\hline \multicolumn{2}{|c|}{$\mathrm{R} 2$} & $0.714^{\mathrm{b}}$ & $233.672^{\mathrm{bc}}$ & $326.938^{\mathrm{bc}}$ \\
\hline \multicolumn{2}{|c|}{ R3 } & $0.728^{\mathrm{b}}$ & $250.614^{\mathrm{b}}$ & $344.063^{\mathrm{ab}}$ \\
\hline \multicolumn{2}{|c|}{$\mathrm{R} 4$} & $0.828^{\mathrm{a}}$ & $293.778^{a}$ & $355.313^{\mathrm{a}}$ \\
\hline \multicolumn{5}{|c|}{ Effect of collection period: } \\
\hline \multicolumn{2}{|c|}{$W 5^{\text {th }}$} & 0.704 & $198.556^{\mathrm{c}}$ & $282.563^{\mathrm{d}}$ \\
\hline \multicolumn{2}{|c|}{$\mathrm{W} 6^{\text {th }}$} & 0.740 & $234.498^{\mathrm{b}}$ & $315.625^{\mathrm{c}}$ \\
\hline \multicolumn{2}{|c|}{$\mathrm{W} 7^{\text {th }}$} & 0.766 & $270.578^{a}$ & $352.813^{\mathrm{b}}$ \\
\hline \multicolumn{2}{|c|}{ W $8^{\text {th }}$} & 0.764 & $290.725^{a}$ & $379.375^{\mathrm{a}}$ \\
\hline \multicolumn{5}{|c|}{ Interaction } \\
\hline \multirow{4}{*}{$\mathrm{R} 1$} & $\mathrm{~W} 5^{\text {th }}$ & 0.695 & 191.625 & 275.000 \\
\hline & $\mathrm{W}^{\text {th }}$ & 0.665 & 191.975 & 287.500 \\
\hline & $\mathrm{W} 7^{\text {th }}$ & 0.738 & 252.125 & 333.750 \\
\hline & $\mathrm{W} 8^{\text {th }}$ & 0.718 & 229.450 & 320.000 \\
\hline \multirow{4}{*}{$\mathrm{R} 2$} & $\mathrm{~W} 5^{\text {th }}$ & 0.633 & 171.663 & 272.750 \\
\hline & $\mathrm{W}^{\text {th }}$ & 0.753 & 229.575 & 305.000 \\
\hline & $\mathrm{W} 7^{\text {th }}$ & 0.713 & 259.875 & 370.000 \\
\hline & $\mathrm{W} 8^{\text {th }}$ & 0.760 & 273.575 & 360.000 \\
\hline \multirow{4}{*}{ R3 } & $\mathrm{W} 5^{\text {th }}$ & 0.715 & 201.938 & 285.000 \\
\hline & $\mathrm{W}^{\text {th }}$ & 0.710 & 226.205 & 320.000 \\
\hline & $\mathrm{W} 7^{\text {th }}$ & 0.738 & 260.938 & 353.750 \\
\hline & $\mathrm{W} 8^{\text {th }}$ & 0.750 & 313.375 & 417.500 \\
\hline \multirow{4}{*}{$\mathrm{R} 4$} & $\mathrm{~W} 5^{\text {th }}$ & 0.775 & 229.000 & 297.500 \\
\hline & $\mathrm{W}^{\text {th }}$ & 0.833 & 290.235 & 350.000 \\
\hline & $\mathrm{W} 7^{\text {th }}$ & 0.875 & 309.375 & 353.750 \\
\hline & $\mathrm{W} 8^{\text {th }}$ & 0.828 & 346.500 & 420.000 \\
\hline \multicolumn{5}{|l|}{$\mathrm{p}$-value } \\
\hline \multicolumn{2}{|c|}{ experimental diets } & 0.001 & $<0.0001$ & 0.001 \\
\hline \multicolumn{2}{|c|}{ Collection period } & 0.165 & $<0.0001$ & $<0.0001$ \\
\hline \multicolumn{2}{|c|}{ Interaction } & 0.811 & 0.477 & 0.203 \\
\hline
\end{tabular}

$a, b, c, d$ Means have different superscripts in the same Column are significantly different at $(P<0.05)$,

The interaction effects appeared on advanced sperm motility and sperm abnormalities but were not clear on percentage of dead spermatozoa. The results show that the advanced sperm motility was significantly $(\mathrm{P}<0.05)$ higher for $\mathrm{R} 2, \mathrm{R} 3$ and $\mathrm{R} 4$ compared with $\mathrm{R} 1$ at $\mathrm{W} 6^{\text {th }}, \mathrm{W}^{\text {th }}$ and $\mathrm{W} 8^{\text {th }}$, respectively. However, sperm abnormalities were significantly $(\mathrm{P}<0.05)$ decreased in R4 compared with R1 at W6 ${ }^{\text {th }}$ and in R2, R3 and R4 compared with R1 at $\mathrm{W}^{\text {th }}$.

These results indicated that rabbits received the probiotics (R2, R3 and R4) had beneficial effects on motility, abnormality and dead spermatozoa.

Results in Table (4) showed the effect of probiotics addition on the male sexual capability measured by lido and level of testosterone hormone as well as initial fructose level. The results of current study 
show an improvement in these traits by adding diets with probiotics compared to the control group in spite of the differences were not significant. There were significant $(\mathrm{P}<0.05)$ effects of collection period on libido that decreased at $\mathrm{W} 6^{\text {th }}, \mathrm{W} 7^{\text {th }}$ and $\mathrm{W} 8^{\text {th }}$ compared with $\mathrm{W} 5^{\text {th }}$. However, the interaction effect was not significant.

Table (3): Effect of the experimental diets, collection period and their interaction on some of physical sperm characteristics.

\begin{tabular}{|c|c|c|c|c|}
\hline \multirow[t]{2}{*}{ Item } & & \multicolumn{3}{|c|}{ Sperm characteristics (mean) } \\
\hline & & $\begin{array}{c}\text { Advanced sperm } \\
\text { motility, } \%\end{array}$ & $\begin{array}{c}\text { Sperm abnormalities, } \\
\%\end{array}$ & Dead spermatozoa, $\%$ \\
\hline \multicolumn{5}{|c|}{ Effect of experimental diets: } \\
\hline & & $67.875^{\mathrm{c}}$ & $25.188^{\mathrm{a}}$ & $26.000^{\mathrm{a}}$ \\
\hline & & $77.500^{\mathrm{b}}$ & $23.000^{\mathrm{bc}}$ & $26.938^{\mathrm{a}}$ \\
\hline & & $81.000^{\mathrm{ab}}$ & $23.125^{\mathrm{bc}}$ & $21.563^{\mathrm{b}}$ \\
\hline & & $82.375^{\mathrm{a}}$ & $21.438^{\mathrm{c}}$ & $19.875^{\mathrm{b}}$ \\
\hline \multicolumn{5}{|c|}{ Effect of collection period: } \\
\hline & & $71.438^{\mathrm{b}}$ & $26.125^{\mathrm{a}}$ & $25.938^{\mathrm{a}}$ \\
\hline & & $74.938^{\mathrm{b}}$ & $22.000^{\mathrm{b}}$ & $27.938^{\mathrm{a}}$ \\
\hline & & $81.500^{\mathrm{a}}$ & $23.313^{\mathrm{b}}$ & $19.750^{\mathrm{b}}$ \\
\hline & & $80.875^{\mathrm{a}}$ & $21.313^{\mathrm{b}}$ & $20.750^{\mathrm{b}}$ \\
\hline \multicolumn{5}{|c|}{ Interaction effect: } \\
\hline \multirow{4}{*}{$\mathrm{R} 1$} & $\mathrm{~W} 5^{\text {th }}$ & $68.750^{\mathrm{ed}}$ & $25.250^{\mathrm{bcd}}$ & 26.250 \\
\hline & $\mathrm{W} 6^{\text {th }}$ & $68.500^{\text {ed }}$ & $25.000^{\mathrm{bcd}}$ & 28.750 \\
\hline & $\mathrm{W} 7^{\text {th }}$ & $67.500^{\mathrm{e}}$ & $28.750^{\mathrm{b}}$ & 24.750 \\
\hline & $\mathrm{W} 8^{\text {th }}$ & $66.750^{\mathrm{e}}$ & $21.750^{\mathrm{de}}$ & 24.250 \\
\hline \multirow{4}{*}{$\mathrm{R} 2$} & W5 $5^{\text {th }}$ & $74.500^{\text {bcde }}$ & $26.250^{\mathrm{bcd}}$ & 27.750 \\
\hline & $\mathrm{W}^{\text {th }}$ & $77.750^{\mathrm{bc}}$ & $23.250^{\text {cde }}$ & 30.250 \\
\hline & $\mathrm{W} 7^{\text {th }}$ & $78.250^{\mathrm{bc}}$ & $21.500^{\mathrm{de}}$ & 23.250 \\
\hline & $W 8^{\text {th }}$ & $79.500^{b}$ & $21.000^{\mathrm{de}}$ & 26.500 \\
\hline \multirow{4}{*}{ R3 } & $\mathrm{W}^{\text {th }}$ & $72.500^{\text {bcde }}$ & $25.500^{\mathrm{bcd}}$ & 24.750 \\
\hline & $\mathrm{W} 6^{\text {th }}$ & $76.250^{\text {bcd }}$ & $21.000^{\mathrm{de}}$ & 29.250 \\
\hline & $\mathrm{W} 7^{\text {th }}$ & $87.000^{\mathrm{a}}$ & $21.500^{\mathrm{de}}$ & 14.750 \\
\hline & $\mathrm{W} 8^{\text {th }}$ & $88.250^{\mathrm{a}}$ & $24.500^{\text {bcd }}$ & 17.500 \\
\hline \multirow{4}{*}{ R4 } & $\mathrm{W} 5^{\text {th }}$ & $70.000^{\text {cde }}$ & $27.500^{b c}$ & 25.000 \\
\hline & $\mathrm{W} 6^{\text {th }}$ & $77.250^{\mathrm{bc}}$ & $18.750^{\mathrm{e}}$ & 23.500 \\
\hline & $\mathrm{W} 7^{\text {th }}$ & $93.250^{\mathrm{a}}$ & $21.500^{\mathrm{de}}$ & 16.250 \\
\hline & $\mathrm{W} 8^{\text {th }}$ & $89.000^{\mathrm{a}}$ & $18.000^{\mathrm{e}}$ & 14.750 \\
\hline \multicolumn{5}{|c|}{ P-value: } \\
\hline \multicolumn{2}{|c|}{ experimental diets } & $<0.0001$ & 0.020 & 0.001 \\
\hline \multicolumn{2}{|c|}{ Collection period } & $<0.0001$ & 0.001 & $<0.0001$ \\
\hline \multicolumn{2}{|c|}{ Interaction } & 0.000 & 0.023 & 0.449 \\
\hline
\end{tabular}

$a, b, c, d, e$ Means have different superscripts in the same Column are significantly different at $(P<0.05)$,

The enhancement of semen quality in rabbits fed diets supplemented with probiotics especially Bacillus s. and Saccharomyces c. mixture could be associated with higher concentration of testosterone recorded for these groups (Table 4). Particularly, semen ejaculate volume, total sperm output and sperm cell concentration, were improved, in addition to seminal plasma fructose which are testosterone dependent process (Fujihara et al., 1983; El-Sherbiny, 1994; Hafez and Hafez, 2000; Hashim et al., 2013). In support to this idea, there was an increase in ejaculate volume, sperm motility and sperm concentration when male rabbits treated with testosterone (ElKelawy and Aboulnaga 1995). 
Table (4): Libido, testosterone hormone and initial fructose of adult rabbit bucks fed the experimental diets, collection period and their interaction.

\begin{tabular}{|c|c|c|c|c|}
\hline \multirow[t]{2}{*}{ Item } & & \multicolumn{3}{|c|}{ Sperm characteristics (mean) } \\
\hline & & $\begin{array}{l}\text { Reaction time } \\
\text { (Libido), sec. }\end{array}$ & $\begin{array}{c}\text { Testosterone conc. } \\
(\mathrm{ng} / \mathrm{ml})\end{array}$ & $\begin{array}{l}\text { Initial fructose conc. } \\
(\mathrm{mg} / \mathrm{dl})\end{array}$ \\
\hline \multicolumn{5}{|c|}{ Effect of experimental diets: } \\
\hline \multicolumn{2}{|c|}{ R1 } & 10.000 & 2.331 & 263.588 \\
\hline \multicolumn{2}{|c|}{$\mathrm{R} 2$} & 8.125 & 2.663 & 272.528 \\
\hline \multicolumn{2}{|c|}{ R3 } & 8.438 & 2.650 & 289.813 \\
\hline \multicolumn{2}{|c|}{$\mathrm{R} 4$} & 8.250 & 2.756 & 307.420 \\
\hline \multicolumn{5}{|c|}{ Effect of collection period: } \\
\hline \multicolumn{2}{|c|}{$W 5^{\text {th }}$} & $10.563^{\mathrm{a}}$ & 2.556 & 296.199 \\
\hline \multicolumn{2}{|c|}{$\mathrm{W}^{\mathrm{th}}$} & $9.625^{\mathrm{ab}}$ & 2.675 & 286.141 \\
\hline \multicolumn{2}{|c|}{$\mathrm{W} 7^{\text {th }}$} & $7.813^{\mathrm{bc}}$ & 2.725 & 250.965 \\
\hline \multicolumn{2}{|c|}{$W 8^{\text {th }}$} & $6.813^{\mathrm{c}}$ & 2.444 & 300.043 \\
\hline \multicolumn{5}{|c|}{ Interaction } \\
\hline \multirow{4}{*}{$\mathrm{R} 1$} & $\mathrm{~W} 5^{\text {th }}$ & 9.250 & 2.725 & 271.303 \\
\hline & $\mathrm{W}^{\text {th }}$ & 10.500 & 2.750 & 263.030 \\
\hline & $\mathrm{W}^{\text {th }}$ & 10.750 & 2.975 & 233.903 \\
\hline & $\mathrm{W} 8^{\text {th }}$ & 9.500 & 2.575 & 286.115 \\
\hline \multirow{4}{*}{$\mathrm{R} 2$} & W5 $5^{\text {th }}$ & 10.500 & 2.500 & 271.300 \\
\hline & $\mathrm{W}^{\text {th }}$ & 8.500 & 2.725 & 271.343 \\
\hline & $\mathrm{W} 7^{\text {th }}$ & 6.500 & 2.825 & 255.168 \\
\hline & $\mathrm{W} 8^{\text {th }}$ & 7.000 & 2.550 & 292.303 \\
\hline \multirow{4}{*}{ R3 } & $\mathrm{W}^{\text {th }}$ & 11.750 & 2.525 & 321.128 \\
\hline & $\mathrm{W}^{\text {th }}$ & 10.000 & 2.175 & 289.083 \\
\hline & $\mathrm{W} 7^{\text {th }}$ & 7.000 & 2.300 & 231.163 \\
\hline & W $8^{\text {th }}$ & 5.000 & 2.325 & 317.878 \\
\hline \multirow{4}{*}{$\mathrm{R} 4$} & $\mathrm{~W}^{\text {th }}$ & 10.750 & 2.475 & 321.065 \\
\hline & W $6^{\text {th }}$ & 9.500 & 3.050 & 321.110 \\
\hline & $\mathrm{W} 7^{\text {th }}$ & 7.000 & 2.800 & 283.628 \\
\hline & $W 8^{\text {th }}$ & 5.750 & 2.325 & 303.878 \\
\hline \multicolumn{5}{|l|}{ P-value: } \\
\hline \multicolumn{2}{|c|}{ experimental diets } & 0.155 & 0.329 & 0.435 \\
\hline \multicolumn{2}{|c|}{ Collection period } & 0.001 & 0.656 & 0.308 \\
\hline \multicolumn{2}{|c|}{ Interaction } & 0.264 & 0.963 & 0.997 \\
\hline
\end{tabular}

$a, b, c$, Means have different superscripts in the same Column are significantly different at $(P<0.05)$,

\section{CONCLUSION}

In conclusion adding buck's diets with either Bacillus s. or Saccharomyces $c$. showed significant $(\mathrm{P}<0.05)$ enhancement of reproductive parameters however, the most beneficial effect was observed when both probiotics were combined in diet (50\% Bacillus s. and $50 \%$ live Saccharomyces $c$.).

\section{REFERENCES}

Castellini C.; Lattaioli P.; Bosco A.D.; Minelli Aand Mugnai C. (2003). Oxidative status and semen characteristics of rabbit buck as affected by dietary vitamin E, C and n-3 fatty acids. Reprod. Nutr. Dev., 43: 91-103. doi:10.1051/rnd:2003008.

Daader, A.H.; H.A. Gabr and T.S.T. Seleem (1999a). Reproductive performance of Californian rabbits as affected by season of the year and oxytocin or adrenaline. 1st International Conference on Indigenous Versus Acclimatized Rabbits, 7-9 Sept., El-Arish, North-Sinai, Egypt, 299-311. 
Daader, A.H.; H.A. Gabr and T.S.T. Seleem (1999b). Productive and reproductive performance of NewZealand White and Californian rabbit bucks as affected by supplementing vitamin "A" to the diet, during summer and winter seasons. 7 th Science Conference on Animal Nutrition, 19-21 Octob., ElArish, North-Sinai, Egypt, 551-564.

Duncan, D.B. (1955). Multiple Range and Multiple (F-test). Biometrics, 11: 1-42.

El-Badawi, A.Y., F.I.S. Helal, M.H. M.Yacout, A.A. Hassan, Soad El-Naggar and Eman H. Elsabaawy (2017). Growth performance of male NZW rabbits fed diets supplemented with beneficial bacteria or live yeast. AgricEngInt: CIGR Journal. Special issue: 220-226.

ElKelawy, H.M. and A.I. Aboulnaga (1995). Effect of testosterone treatment on reproductive efficiency of growing and poor fertile male rabbits.Egyptian J. Rabbit Sci. 5 (2): 89-100.

El-Sherbiny, A.M. (1994). Some Reproductive Aspects of Male Rabbits. Ph.D. Thesis, Fac. Agric., Ain Shams Univ., Cairo, Egypt.

Ewuola, E.O. (2013). Daily sperm production, gonadal and extragonadal sperm reserves of rabbits fed prebiotic and probiotic supplemented diets. Int. J. Appl. Agric. Apic. Res., 9: 48-53.

F.A.O. (1987). Rabbit production. $12^{\text {th }}$ Session of the F.A.O. Regional Animal Production and Health commission for Asia and Pacific Held in Islamabad, Pakistan from $5^{\text {th }}$ to $10^{\text {th }}$ October.

Fujihara, N.; O. Koga and H. Nishiyama (1983). Secretory function of the ductus deferens of male chickens. Poultry Sci.62 (3): 557-560.

Hafez, E.S.E. and B. Hafez (2000). Reproduction in farm animals. 7th ed., Lippincott Williams \& Wilkins; Philadelphia, Baltimore, New York, London, Buenus Aires, Hong Kong, Sydney and Tokyo.

Hashim, N.M.; A. Abd El-Hady and O. Hassan (2013). Effect of vitamin E or propolis supplementation on semen quality, oxidative status and hemato-biochemical changes of rabbit bucks during hot season. Livestock Sci. 157 (2): 520-526.

Mann, T. (1948). Fructose content and fructolysis in semen. Practical application in evaluation of semen quality, J. Agric. Sci., 38: 323-331.

McDaniel, G. R., and T. Sefton (1991). Effect of yeast culture (Yeasacc1026) supplementation on broiler breeders. Poult. Sci. 70(Suppl. 1):172. (Abstr.).

Mymrin V.S.; Khalturina L.V. and Lebedeva I.A. (2017). Effect of probiotic product "bacell" on improvement of stud bulls semen quality.http://www.biotechagro.ru/articles/cattle/docs/bacell.

NRC (1994). Nutrient Requirements of Rabbits. 2nd Ed. National Academy of Science, Washington, DC. USA.

Osman, Noha, A.M. (2005). Influence of supplemental probiotic on immunological, hematological and productive performance in growing rabbits. M. Sc. Thesis, Agric. Fac., Cairo Univ., Egypt.

Rashwan, A.A. and I.F.M. Marai (2001). Mortality in rabbits: causes and its control. $2^{\text {nd }}$ Inter. Conf. on Anim. Prod. and Health in Semi-Arid Areas, 4-6 Sep., Al-Arish, North-Sinai, Egypt, 41-56.

Salisbury, G.W.; N.L. Van Demark; and J.R. Lodge (1978). Physiology of Reproduction and Artificial Insemination of Cattle. W.H. Freeman and Company, San Francisco, USA.

SAS (2001). SAS User's Guide Statistic. SAS Version 8.2. Inc. Cary. NC. USA.

Schrezenmeir, J. and de Vrese, M. (2001): Probiotics, prebiotics, and synbiotics--approaching a definition. Am. J. Clin. Nutr., (2):361-364.

Seleem, T.S.T. (2003). Studies on productive and physiological characteristics of rabbits under different managerial conditions. Ph.D. Thesis, Faculty of Agriculture, Zagazig University, Zagazig, Egypt.

Seleem, T.S.T.; H. Ibrahim; A.M. Ali; A.M. Abd-Elmotaal and A.E.B. Zeidan (2007a). Rabbit performance as affected by Origanum Majorana in diets. $5^{\text {th }}$ Inter. Conf. on rabbit production in Hot Clim., Hurghada, Egypt, 454-508.

Sissons, J. (1989): Potential of probiotic organisms to prevent diarrhea and promote digestion in farm animals. J. Sci. Food Agric., (49): 1-14.

Steel, R.G.D. and Torrie, J.H. (1980). Principles and Procedures of Statistics. A biometrical approach. 2nd edition. McGraw-Hill, New York, USA, pp. 20-90. 


\section{Helal et al.}

Valcarce, D.G. ; S. Genovés ; M.F. Riesco; P. Martorell; M.P. Herráez ; D. Ramón and V. Robles (2017) Probiotic administration improves sperm quality in asthenozoospermic human donors. Benef Microbes. (2017) 26;8(2):193-206.

Vershuere, L.; G. Rombaut ; P.Sorgeloos and W. Verstraete (2000) Probiotic bacteria as biological control agents in aquaculture. Microbiol Mol Biol Rev 64(4):655-671.

مقاييس جودة السائل المنوى لذكور الارانب النيوزيلاندى المغذاة على علائق مضاف اليها نوعين من البروبيوتيك

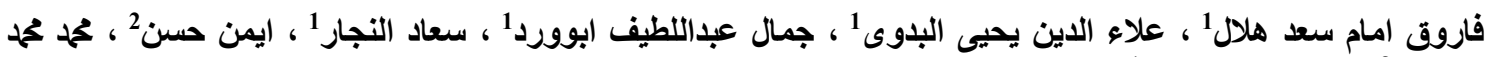

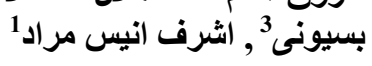
أقسم الاتتاج الحيوانس- المركز القومى للبحوثـ الدقى - الجبزة.

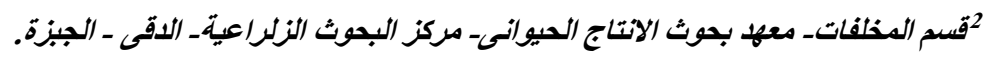

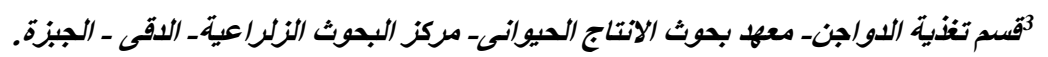

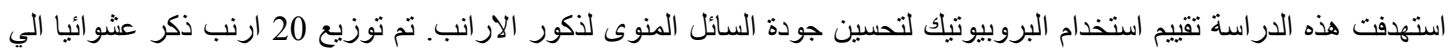

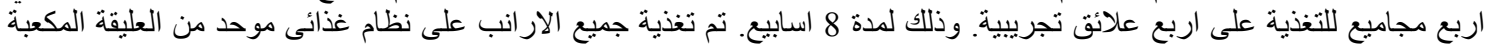

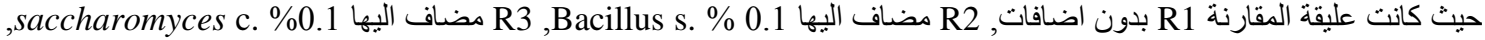

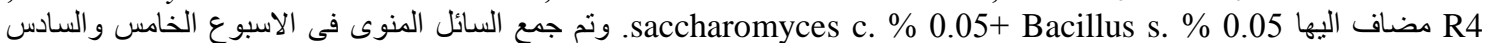

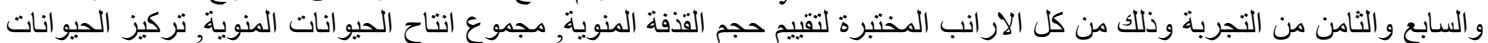

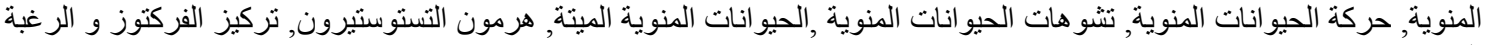
الجنسية.

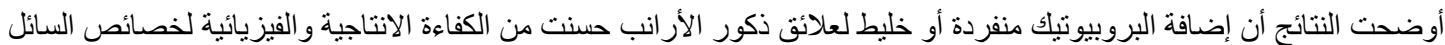

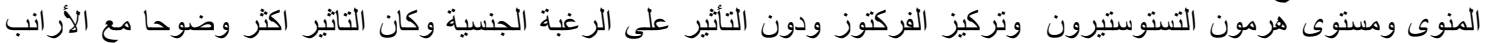

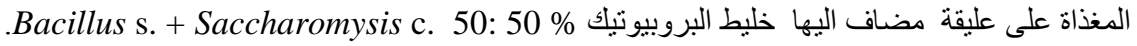

